\title{
Remarks on the Oecology of Coniferae.
}

\author{
BY
}

\author{
PERCY GROOM, M.A., D.Sc., F.L.S. \\ Assistant Professor of Botany, Imperial College of Science and Technology, London.
}

$\mathrm{T}^{\mathrm{N}}$ this paper I propose to discuss three problems concerning the 1 Coniferae, namely :-

I. The cause of their xerophytic foliage and tracheidal wood.

2. The cause of their survival in competition with dicotylous trees.

3. The cause of the suppression of many forms in past ages.

As the physiology of the Coniferae is known only in regard to northtemperate forms, the discussion will solely concern these.

The evergreen nature of the Gymnospermae has long been admitted to be primitive in the class, and in the sub-group Coniferae. The evergreen leaves of Coniferae display xeromorphy in their relatively and usually absolutely small surface, and exhibit xerophytic structure in their epidermal structure and often in other respects (hypoderma). Even the deciduous larch shows these ancestral features stamped on the form, and, to a slight extent, on the epidermal structure of the leaves.

The xeromorphy and xerophytic structure of evergreen coniferous leaves were, for a time, regarded as providing protection against the cold of winter, and against injury by excessive loads of snow.

If this explanation were regarded as adequate, we should be compelled to assume that Coniferae living in warm temperate or sub-tropical climes had migrated from cold temperate regions.

Another explanation was offered by A. F. W. Schimper ('90), according to whom the evergreen nature of the Coniferae must be combined with a slow rate of transpiration, because during the physiologically dry season-the cold season in cold temperate regions-absorption of water is largely arrested.

That this explanation, which accounts for the survival of Coniferae in north-temperate regions where there is a physiologically dry season, may not be a complete rationale of the origin and persistence of the coniferous mechanism is suggested by:-

I. The wide range of distribution as regards climate and habit of Coniferae.

[Annals of Botany, Vol. XXIV. No. XCIV. April, rgio.] 
2. The occurrence of Coniferae in evergreen tropical humid regions. ${ }^{1}$

3. The demand on the part of certain cold-temperate Coniferae for a relatively humid habitat. ${ }^{1}$

I propose, therefore, to discuss several points in connexion with the coniferous mechanism in relation to water.

(a) The Coniferous Mechanism does not necessarily involve a Slow Rate of Transpiration per Unit Surface of Leaf, Nor Xerophytic Structure in the Leaf.

Though the xerophytic structure of the evergreen Conifer leaf is associated with a slow rate of transpiration, the deciduous larch-leaf transpires rapidly. This is shown by results obtained by Von Höhnel ('80).

The subjoined statistics record the number of grammes of water transpired per gramme air-dry weight of leaf-substance during the period April I to September 31, I 879. (Von Höhnel's results have been converted into approximate numbers.)

\begin{tabular}{|c|c|c|c|c|}
\hline Sorbus torminalis & $\cdots$ & $\ldots$ & $\left.1,75^{\circ}\right)$ & \\
\hline Larix decidua & $\ldots$ & $\ldots$ & $\mathrm{I}, \mathrm{I} 50$ & \\
\hline Tilia grandifolia & $\ldots$ & $\ldots$ & $\mathrm{I}, \mathrm{O} 3 \mathrm{O}$ & \\
\hline Fagus sylvatica & $\ldots$ & & 860 & \\
\hline Betula alba $\quad \ldots$ & $\ldots$ & $\ldots$ & $845\}$ & Deciduous \\
\hline Elm $\quad \ldots \quad \ldots$ & $\ldots$ & $\ldots$ & 755 & \\
\hline Quercus Robur & $\ldots$ & $\ldots$ & 660 & \\
\hline Acer platanoides & $\ldots$ & $\ldots$ & 520 & \\
\hline Picea excelsa ... & $\ldots$ & $\ldots$ & 210 & \\
\hline Pinus sylvestris & $\ldots$ & $\ldots$ & 105 & \\
\hline Pinus Laricio ... & $\ldots$ & $\ldots$ & 100 & Evergreen \\
\hline Abies pectinata & $\ldots$ & $\ldots$ & 75 & \\
\hline
\end{tabular}

But these results do not necessarily imply all they seem to, as misconception will arise if Von Höhnel's method of calculation and mode of experiment are not taken into account.

This will be clear, so far as the method of calculation is concerned, from the following example. If we suppose that there are two flat leaves, say a sun-leaf and a shade-leaf of the same species and of equal surface, and that the former leaf weighs twice as much as the latter; then, if the sun-leaf under the influence of direct sunlight is transpiring twice as much water in a given time as the shade-leaf in weak diffused light, the rate of transpiration will nevertheless seem to be the same in the two leaves if we estimate according to Von Höhnel's method, that is, per gramme dry

${ }_{1}$ Compare Schimper, 1898. English Version, pp. 564-5. 
weight of leaf. The effect of the misconception arising becomes obvious when we examine the results obtained by Von Höhnel in connexion with different specimens of one species. Von Höhnel conducted his observations by means of potted plants, the pots and soil being protected from direct evaporation. He periodically weighed and watered the plants (and pots). One set of plants he kept in a well lighted position, and the other set in a constantly shaded position. Examining his statistics, the latter plants seem to be transpiring more rapidly than the plants exposed to sunlight. Von Höhnel sought to explain this as partly due to the fact that the shaded leaves were not exposed to rain or dew, that the structure of the shade-leaves is such as to promote rapid transpiration, and finally that the soil was moister in the shade. The first and third alleged causes were probably operative, and may well account for the truly greater transpiration per unit leaf-surface of some of the plants in the shade; but the second assigned reason is not justifiable. The explanation of the apparently greater transpiration of the shaded leaves lies chiefly in their lighter weight: for I find that when judging either by absolute amount of water transpired by the whole plant or by the weight of transpiration per square centimetre of leaf-surface, the leaves exposed to the light in most cases transpired more rapidly. This is proved by an inspection of columns 3 and 4 (giving Von Höhnel's results) and columns 5 to 8 (giving my calculations) of Table I.

It is, therefore, possible that the estimate given above of Sorbus torminalis is too high, for I notice that it refers to a solitary shaded specimen.

In Table I the estimates of the leaf-surface of the dicotylous plants are Von Höhnel's; those of the Conifers are mine, and result from numerous measurements of the surfaces of leaves combined with Von Höhnel's statistics as regards the numbers and lengths of the leaves. The following were my results :-

DIMENSIONS OF CONIFEROUS LEAVES.

\begin{tabular}{|c|c|c|c|c|}
\hline & \multicolumn{2}{|r|}{ In Sunlight. } & \multicolumn{2}{|r|}{ In Shade. } \\
\hline & $\begin{array}{l}\text { Mean } \\
\text { length. }\end{array}$ & $\begin{array}{l}\text { Mean perimeter or } \\
\text { width of cross section. }\end{array}$ & $\begin{array}{l}\text { Mean } \\
\text { Length. }\end{array}$ & $\begin{array}{l}\text { Mean perimeter or } \\
\text { width of cross section. }\end{array}$ \\
\hline $\begin{array}{l}\text { Pinus sylvestris } \\
\text { Picea excelsa. }\end{array}$ & $47.3 \mathrm{~mm}$. & $\begin{array}{l}3.48 \mathrm{~mm} . \\
2.88\end{array}$ perimeter. & $54.75 \mathrm{~mm}$. & $3.32 \mathrm{~mm}$.$\} perimeter.$ \\
\hline Abies pectinata & I 2 & $2 \quad " 1$ & - & - \\
\hline Larix decidua. & $27 \cdot 2 \quad$, & $0.713,,\}^{\text {mean width. }}$ & $23 \cdot 1$ & 0.862, \\
\hline
\end{tabular}




\section{TABLE I.}

\begin{tabular}{|c|c|c|c|c|c|c|c|c|c|c|}
\hline \multicolumn{4}{|c|}{ I. } & $\begin{array}{c}\text { II. } \\
\text { Aggregate } \\
\text { leaf sur- } \\
\text { face of the } \\
\text { tree in } \\
\text { sq. } \mathrm{cm} .\end{array}$ & $\begin{array}{l}\text { III. } \\
\text { Absolut } \\
\text { of wat } \\
\text { spired } \\
\text { Dec. } \\
\text { in gr }\end{array}$ & $\begin{array}{l}\text { IV. } \\
\text { amount } \\
\text { r tran- } \\
\text { une I to } \\
\text { I } 878 \text {, } \\
\text { mmes. }\end{array}$ & $\begin{array}{l}\text { V. } \\
\text { Numb } \\
\text { grammes } \\
\text { transpirea } \\
\text { to Sept. I } \\
\text { per sq. }\end{array}$ & $\begin{array}{l}\text { VI. } \\
\text { of } \\
\text { water } \\
\text { June I } \\
\text { I } 878 \text {, } \\
\mathrm{cm} \text {. }\end{array}$ & \multicolumn{2}{|c|}{$\begin{array}{c}\text { VII. VIII. } \\
\text { Minimumnum- } \\
\text { ber of grammes } \\
\text { of water tran- } \\
\text { spired in one of } \\
\text { the months June } \\
\text { to Aug. } 3 \text { I per } \\
\text { sq. cm. }\end{array}$} \\
\hline $\begin{array}{r}\text { I } \\
\text { I } 4 \\
\text { I } 8\end{array}$ & $\begin{array}{c}\text { Quercus } \\
, " \\
",\end{array}$ & $\begin{array}{c}\text { Cerris } \\
,, \\
,,\end{array}$ & $\begin{array}{c}\text { Shade } \\
\text { Sun } \\
,,\end{array}$ & $\begin{array}{l}1,764 \\
3,316 \\
3,35^{6}\end{array}$ & $\begin{array}{l}\text { Sun. } \\
\begin{array}{l}1,975 \\
2,35^{2}\end{array}\end{array}$ & $\begin{array}{l}\text { Shade. } \\
2,065\end{array}$ & $\begin{array}{l}\text { Sun. } \\
\begin{array}{l}0.49 \\
0.58\end{array}\end{array}$ & $\begin{array}{l}\text { Shade. } \\
0.83\end{array}$ & $\begin{array}{l}\text { Sun. } \\
\text { 0.1 } 40 \\
0.135\end{array}$ & $\begin{array}{c}\text { Shade. } \\
\text { O.II3 }\end{array}$ \\
\hline $\begin{array}{r}3 \\
21 \\
55 \\
59\end{array}$ & $\begin{array}{c}\text { Carpinus } \\
\text { ", } \\
\text { ", }\end{array}$ & $\begin{array}{c}\text { setulus } \\
, " \\
",\end{array}$ & $\begin{array}{c}\text { Shade } \\
\text { Sun } \\
\text {, }\end{array}$ & $\begin{array}{r}842 \\
1,829 \\
\mathrm{I}, 624 \\
\mathrm{I}, 3^{8} 5\end{array}$ & $\begin{array}{l}3,848 \\
2,568\end{array}$ & $\begin{array}{r}504 \\
\mathrm{I}, 337\end{array}$ & $\begin{array}{l}I \cdot 9 \\
I \cdot 43\end{array}$ & $\begin{array}{l}0.4^{2} \\
0.45\end{array}$ & 0.43 & O.I I 3 \\
\hline $\begin{array}{l}28 \\
29 \\
53 \\
62 \\
30 \\
54 \\
65\end{array}$ & $\begin{array}{c}\text { Fagus sy } \\
\text { ", } \\
\text {," } \\
\text {," } \\
\text { ", }\end{array}$ & $\begin{array}{l}\text { lvatica } \\
\text { ", } \\
\text { ", } \\
\text { ", } \\
\text { ", }\end{array}$ & $\begin{array}{c}\text { Shade } \\
\text { ", } \\
\text { ", } \\
\text { Sun } \\
\text { ", }\end{array}$ & $\begin{array}{r}\mathrm{I}, 776 \\
728 \\
705 \\
365 \\
\mathrm{I}, 803 \\
798 \\
\mathrm{I}, 033\end{array}$ & $\begin{array}{r}2,46 \mathrm{I} \\
\mathrm{I}, 986 \\
85^{8}\end{array}$ & $\begin{array}{r}1,721 \\
1,160 \\
971 \\
510\end{array}$ & $\begin{array}{l}I .02 \\
2.2 \\
0.75\end{array}$ & $\begin{array}{l}0.65 \\
I \cdot 1 \\
0.87 \\
0.9\end{array}$ & O. I 56 & 0.156 \\
\hline & $\begin{array}{c}\text { Betula } \\
, ", \\
, ", \\
, ",\end{array}$ & lba & $\begin{array}{c}\text { Shade } \\
\text { Sun } \\
\text { " }\end{array}$ & $\begin{array}{r}707 \\
462 \\
987 \\
\mathrm{I}, 418\end{array}$ & $\begin{array}{l}2,5^{2} 3 \\
4,154\end{array}$ & $\begin{array}{l}I, 868 \\
I, 740\end{array}$ & $\begin{array}{l}2 \cdot 2 \\
I \cdot 55\end{array}$ & $\begin{array}{l}1.92 \\
2.66\end{array}$ & 0.545 & $0.55^{8}$ \\
\hline $\begin{array}{l}\text { I6 } \\
\text { I } 7 \\
\text { I } 5 \\
56\end{array}$ & $\begin{array}{c}\text { Fraxinu } \\
\text { ", } \\
\text { ", }\end{array}$ & $\begin{array}{c}\text { ex excelsior } \\
", \\
", \\
",\end{array}$ & $\begin{array}{c}\text { Shade } \\
\text { Sun } \\
\text {,, }\end{array}$ & $\begin{array}{l}\mathrm{I}, 5 \circ 3 \\
\mathrm{I}, 940 \\
3,067 \\
\mathrm{I}, 3^{8} 5\end{array}$ & $\begin{array}{l}4,857 \\
4,270\end{array}$ & $\begin{array}{l}1,918 \\
2,987\end{array}$ & $\begin{array}{l}I \cdot 45 \\
2.5\end{array}$ & $\begin{array}{l}0.75 \\
\mathrm{I} \cdot \mathrm{I} 4\end{array}$ & 0.34 & 0.183 \\
\hline $\begin{array}{l}\text { I3 } \\
56\end{array}$ & $\begin{array}{c}\text { Acer Pse } \\
, "\end{array}$ & eudoplatanus & Sun & $\begin{array}{l}2,858 \\
1,085\end{array}$ & $\begin{array}{l}1,657 \\
2,72 \mathrm{I}\end{array}$ & & $\begin{array}{l}0.5^{I} \\
2.1\end{array}$ & & 0.45 & 0.107 \\
\hline $\begin{array}{r}9 \\
\text { I0 } \\
8 \\
\text { I I }\end{array}$ & $\begin{array}{l}\text { Acer pla } \\
,, \\
,, \\
,,\end{array}$ & $\begin{array}{l}\text { tanoides } \\
\text { ", } \\
",\end{array}$ & $\begin{array}{c}\text { Shade } \\
\text { Sun } \\
\text { ». }\end{array}$ & $\begin{array}{l}2,677 \\
I, 466 \\
3,4 \mathrm{I} 2 \\
4,435\end{array}$ & $\begin{array}{l}3,524 \\
2,698\end{array}$ & $\begin{array}{l}1,636 \\
1,368\end{array}$ & $\begin{array}{l}0.87 \\
0.46\end{array}$ & $\begin{array}{l}0.39 \\
0.599\end{array}$ & 0.13 & 0.096 \\
\hline $\begin{array}{l}24 \\
25\end{array}$ & $\begin{array}{c}\text { Tilia gr } \\
\text { " }\end{array}$ & andifolia & $\begin{array}{r}\text { Shade } \\
\text { Sun }\end{array}$ & $\begin{array}{l}\mathrm{I}, \mathrm{OI} 5 \\
\mathrm{I}, \mathrm{I} 38\end{array}$ & 3,094 & $\mathrm{I}, 474$ & $2 \cdot 3$ & $I \cdot 05$ & 0.627 & 0.3 \\
\hline $\begin{array}{l}36 \\
37\end{array}$ & $\begin{array}{c}\text { Picea ex } \\
,,\end{array}$ & celsa & $\begin{array}{c}\text { Sun } \\
" n\end{array}$ & \}$\left(\mathrm{I}_{4}, 25^{6}\right)\{$ & $\begin{array}{l}2,3 \text { I } 5 \\
2,362\end{array}$ & & O.I 3 (mean) & & & \\
\hline $\begin{array}{l}39 \\
47 \\
49 \\
69\end{array}$ & $\begin{array}{c}\text { Pinus sy } \\
\text { Abies pec } \\
\text { ", }\end{array}$ & $\begin{array}{l}\text { lvestris } \\
\text { ctinata } \\
\text { ", }\end{array}$ & $\begin{array}{c}\text { Sun } \\
\text { Shade } \\
\text { Sun }\end{array}$ & $(12,394)$ & 2,840 & $\begin{array}{l}1,986 \\
2,022\end{array}$ & 0.18 & & & \\
\hline
\end{tabular}

Thus Von Höhnel's method of calculation causes the transpiration of evergreen Conifers to seem disproportionately slow, because each leaf has relatively great weight and small surface. Yet when judged by trans- 
piration per square centimetre the evergreen Conifers are seen to transpire very slowly, whereas the larch transpires at a rate equalling that of rapidly transpiring deciduous dicotyledons. This is demonstrated by statistics concerning Von Höhnel's second series of experiments conducted during I $879-80$ as shown below.

In these experiments, as in the earlier ones by Von Höhnel, great differences showed themselves in the rate of transpiration even of the same species and in the same situation. These particular differences, I think, must have been due to differences in the amount of water supplied, as the grave defect of the pot-method of measuring transpiration is that the rate of transpiration is so largely determined by the amount of water supplied to the roots. Moreover parsimonious watering leads to a shedding of the leaves and a further decrease in the apparent rate of transpiration. Hence, to show indubitably the rapid expenditure of water by the larch-needles, I compared their rate of transpiration with the maximum rate attained by dicotylous trees.

The subjoined statistics are derived from my calculations based upon Von Höhnel's results, and they record the approximate maximum transpiration in grammes per square centimetre during the year $1879-80$.

$$
\begin{aligned}
& \begin{array}{llll}
\text { Fagus sylvatica } & \ldots & \ldots & 7 \cdot 5
\end{array} \\
& \begin{array}{llll}
\text { Larix decidua } & \ldots & \ldots & 5 \cdot 4-3 \cdot 4 \\
\text { Quercus Cerris } & \ldots & \ldots & 3 \cdot 2
\end{array} \text { Exposed to } \\
& \begin{array}{lllll}
\text { Betula alba } & \ldots & \ldots & \ldots & 3 \\
\text { Carpinus Betulus } & \ldots & \ldots & 3 \cdot \mathrm{I} 3
\end{array} \text { the light. } \\
& \text { (Larix decidua in half shade I.4.) }
\end{aligned}
$$

In reference to these results, I note the maximum shown by the beech was attained in the smallest specimen, so that it is probable that the high result was due to high rate of watering. Two numbers are given in connexion with the larch exposed to light, because the air-dry weight of larch-needles as measured by Von Höhnel and myself did not agree. Von Höhnel found that Ioo air-dry 'lighted' larch-needles weighed 0.I $65 \mathrm{grm}$.; whereas mine weighed only 0.1034 , while 100 shaded leaves weighed $0.095^{8}$ grm. Hence Von Höhnel's larch-needles were either larger, denser, or less dry; and I have calculated the transpiration according to the first possibility (viz. 3.4 ), as well as according to the surface of the larch-needles measured and weighed by myself (viz. $5 \cdot 4$ ).

The existence of the larch, with its rapidly transpiring leaves, is in itself fatal to Miss Stopes's hypothesis ('07) that Conifers necessarily have a limited rate of transpiration and 'xerophytic' foliage because the wood is incapable of 'allowing a rapid flow of water'. 


\section{(b) The Transpiration Current up the Coniferous Stem MAY BE RAPID.}

In view of the rapid transpiration of the larch, and the consequently rapid flow of water along the tracheides of the leaf, and in view of the large number of leaves borne indirectly or directly on the slender twigs, it seemed to me probable that the transpiration current in the larch would be quite as rapid as in dicotylous trees; and this anticipation was strengthened by the fact that the layer of sap-wood of the larch is unusually narrow.

I therefore made experiments as to the rate of ascent of water by means of the ordinary eosin method, in shoots of Larix decidua, Pseudolarix Kaempferi, Abies pectinata, Pinus sylvestris, and Fagus sylvatica.

The experiments were conducted in such a manner as to give maximum results. They were performed in July, I909, on hot or warm, mainly sunny days, on which a breeze or wind was blowing: the shoots were exposed out of doors to the breeze, and in most cases to direct intense sunlight, or in a minority of cases to strong diffuse light. So far as possible the shoots were selected with a considerable head of foliage, either on a single axis, or on a branched axis which surmounted a considerable basal leafless portion of the stem; thus the current of the solution at the base was not distributed over several stems but travelled up a single axis. The shoots were amputated from the tree in such a manner that the region of severance was under water at the time of severance. Yet care was taken to avoid extreme results due to 'negative pressure', as before being tested with the eosin solution the detached shoots were kept (in some cases in a confined space in darkness) with their cut ends dipping in water for periods varying from 35 minutes up to more than 24 hours. The duration of these preparatory periods designed to do away with ' negative pressure' is recorded in the second vertical column of the succeeding tables.

I was unprepared for the rapidity of ascent of the dye, so that in a number of cases, when measuring the height to which the eosin had ascended in the shoot, I made the first cut, and sometimes some of the subsequent cuts, too low down the stem. The result was that in these cases the transpiring leaves on the upper part of the shoot were still exercising their suctional power and drawing up the eosin solution. Consequently, the time during which the eosin was ascending the stem was considerably greater than that intervening between the moments of placing the shoot in the eosin and removing it from the eosin. At the time of performing the experiments, I unaccountably failed to appreciate the extent to which this would modify the results as regards rate of flow; and I omitted to record the actual moment at which the highest point reached by the eosin was located, or whether, in making the first cut, I had made it above or below the highest 
point reached by the eosin. As, however, my aim is not to give statistics showing the usual rate of ascent of sap, but it is merely to demonstrate that water can and does flow rapidly through coniferous wood under the influence of transpiration, these deficiencies in observation do not matter. In the subjoined tables and calculations I have assumed that the leaves were acting and drawing up the eosin for the maximum time in each case, and have therefore added a 'time-allowance' to the time actually intervening between the moment of dipping the stem in the eosin and removing it. The consequence is that in a number of cases the calculated rate of ascent of the eosin solution is certainly less than the true rate. But where this calculated rate of ascent seems startlingly great, I have been able to prove what was the lowest possible minimum by referring to my notebook and noting the moment at which observations on the next succeeding shoot had commenced. By this method it is proved, for instance, that in the cases of the larch specimens $3,9,10, \mathrm{II}$, and $\mathrm{I} 4$, the lowest possible rates at which the eosin ascended were respectively $\mathrm{I}_{32}, \mathrm{I}_{53}, \mathrm{I}_{3} 8, \mathrm{I} 3 \mathrm{I}$, and $\mathrm{I} 26$ centimetres per hour. The statistics given below, then, must not be regarded as doing more than prove that coniferous wood can and does conduct water at a high speed, and that in the larch the rate may equal that attained under identical external circumstances by a very rapidly transpiring dicotylous tree, such as the beech. In the larch, rates of 204,240 , and $233 \mathrm{~cm}$. per hour were attained, while in the fewer beech shoots experimented upon, the highest speed calculated was 232 .

The calculated rates of ascent in each of the different species varied considerably; for instance, in the case of the larch, between 240 and less than $24 \mathrm{~cm}$. per hour. It is probable that the low rates in the larch may in some cases have been due to the admission of air into the cut end of the stem either at the moment of severance or during transport. In some cases the variation in rate could be correlated with change in the surroundings or differences in the amount of foliage. For instance, in the first set of observations the rates in the cooler, less breezy, less sunny afternoon were less in both the larch and beech than in the morning.

The final table of this series shows the comparative rates of ascent of the eosin in different species under identical external factors, as the measurements made upon the different shoots within $5^{-1} 5$ minutes of one another are recorded on the same horizontal lines of the table.

After the larch and beech, the Scots pine showed the highest speed of flow, namely, $120 \mathrm{~cm}$. per hour, and a minimum of $30 \mathrm{~cm}$. per hour. It thus surpassed in the rate of current the deciduous Psendolarix, whose maximum rate was 78 and minimum 28.5. In Abies pectinata the maximum rate was 60 , and the minimum 35 or $32 \cdot 5$. These results show that even an evergreen Conifer can have a relatively rapid flow of water through its wood; but they must not be regarded as demonstrating the 
relative speeds in the various species, as only three or four shoots of several of the species were experimented upon.

In Ewart's experiments ('05), the maximum rates measured in centimetres per hour for different woody plants were : elder I3I, apple I 2I, elm 205, pear 248, yew 23. Ewart worked with shoots longer (4-8 ft. long) than those I used.

In the subjoined tables the respective vertical columns, commencing at the left hand, represent :-

I. The number by which the shoot was designated.

2. The number of minutes during which the cut shoot remained dipping in water prior to eosin being supplied to it.

3. The number of minutes during which the stem remained dipping in eosin plus the number of minutes during which the eosin may have continued to ascend subsequent to the stem being removed from the eosin solution.

4. The height in centimetres to which the eosin had ascended.

5. The calculated rates of ascent of the eosin in centimetres per hour.

6. Any remarks on the shoots or the results obtained.

LARCH.

(Experiments made in July.)

\begin{tabular}{|c|c|c|c|c|c|c|}
\hline 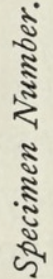 & 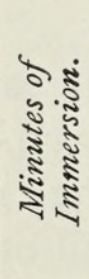 & 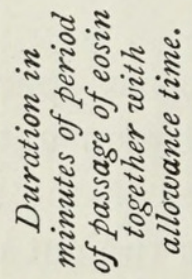 & 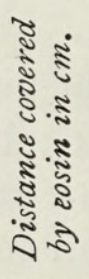 & 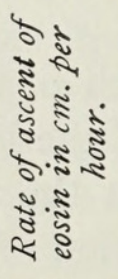 & & - \\
\hline I & 35 & $25 \cdot 5+I$ & 30.5 & $7^{2 \cdot} \cdot 5$ & & Set $I$ \\
\hline 2 & 70 & $10+I$ & I 2 & $6_{5}$ & & \\
\hline 3 & 90 & $13.25+I$ & $4^{2}$ & I 77 & $\begin{array}{l}\text { The dye had entered the foliaged part } \\
\text { of the axis and the measurement is thus } \\
\text { a maximum, but the record of the hour } \\
\text { of the next experiment proves that the } \\
\text { lowest possible minimum rate was } \mathbf{3}^{2} \text {. }\end{array}$ & $\begin{array}{l}\text { Morning: } \\
\text { warm, } \\
\text { breezy, }\end{array}$ \\
\hline 4 & 95 & $20 \cdot 25+I$ & $39+$ & IIO+ & $\begin{array}{l}\text { The dye had reached the terminal bud } \\
\text { of the shoot, so that this measurement } \\
\text { I I o does not record the full rate of } \\
\text { ascent. }\end{array}$ & $\begin{array}{l}\text { shoots } \\
\text { exposed } \\
\text { to direct } \\
\text { sunlight. }\end{array}$ \\
\hline 5 & 120 & $3+I$ & 2.5 & $3^{8 \cdot 5}$ & $\begin{array}{l}\text { This shoot had six long branches and } \\
\text { plenty of foliage: possibly the slow } \\
\text { ascent was due to entrance of air at } \\
\text { the cut end of the stem. }\end{array}$ & \\
\hline 6 & 150 & $5+I$ & $7 \cdot 5$ & 75 & & Afternoon \\
\hline 7 & I 80 & $6+I$ & 9 & 77 & & $\begin{array}{l}\text { less breeze, } \\
\text { not sunny. }\end{array}$ \\
\hline
\end{tabular}




\section{LARCH (continued).}

\begin{tabular}{|c|c|c|c|c|c|c|}
\hline 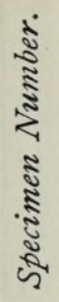 & 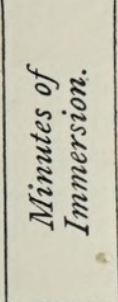 & 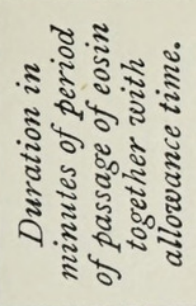 & 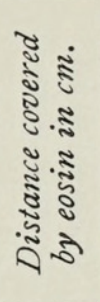 & 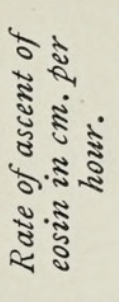 & & \\
\hline I9 & $\begin{array}{c}\text { One } \\
\text { whole } \\
\text { day }\end{array}$ & $7+1$ & I I & 82.5 & $\begin{array}{l}\text { (In this and the other shoots of this } \\
\text { set, before experimenting with eosin, } \\
\text { a piece, } \mathrm{I} \frac{\mathrm{I}}{2}-2 \frac{1}{2} \mathrm{~cm} \text {. in length, was cut } \\
\text { off the lower end of the stem under } \\
\text { water.) This shoot was unbranched, } \\
40 \mathrm{~cm} \text {. long, well foliaged at the end, } \\
\text { and had three isolated tufts of leaves } \\
\text { on the otherwise unfoliaged basal part. } \\
\text { The dye had gone past these three } \\
\text { tufts, but not among the other foliage. }\end{array}$ & Set $I I I$ \\
\hline 20 & $\begin{array}{c}\text { One } \\
\text { whole } \\
\text { day }\end{array}$ & II $\cdot 75+$ I & $3^{I}$ & I I 3 & $\begin{array}{l}\text { This shoot gave off from the lower } \\
\text { unfoliaged part of the stem a long } \\
\text { shoot, so that two measurements are } \\
\text { given, the first recording the ascent of } \\
\text { the eosin up the main stem, and the } \\
\text { second up the basal part of the main } \\
\text { stem and the long branch. In con- } \\
\text { nexion with the second the time was } \\
\text { reckoned as being taken at the con- } \\
\text { clusion of the observations on the } \\
\text { ascent, so that the measurement is } \\
\text { a minimum one. }\end{array}$ & $\begin{array}{l}\text { sunny, } \\
\text { breezy; } \\
\text { shoots } \\
\text { exposed } \\
\text { to direct } \\
\text { sunlight. }\end{array}$ \\
\hline 21 & $\begin{array}{c}\text { One } \\
\text { whole } \\
\text { day }\end{array}$ & $I 3+I$ & I3 & $5^{6}$ & $\begin{array}{l}\text { This slow rate of ascent is possibly } \\
\text { due to entrance of air into stem. }\end{array}$ & \\
\hline 8 & 50 & $9 \cdot 5+I \cdot 5$ & 26 & $I_{4}^{2}$ & $\begin{array}{l}\text { The stem ended in a long leafless } \\
\text { dead part (up which no eosin travelled), } \\
\text { but gave off a long branch foliaged at } \\
\text { its terminal part; otherwise there were } \\
\text { no branches. }\end{array}$ & Set II \\
\hline 9 & 70 & $5+2 \cdot 5$ & $25 \cdot 5$ & 204 & $\begin{array}{l}\text { This shoot bore three long foliaged } \\
\text { branches and ended in a dead part of } \\
\text { the relatively main stem: the measure- } \\
\text { ment is up the main stem and thence } \\
\text { up the topmost foliaged branch. Full } \\
\text { allowance is made for the ascent of } \\
\text { eosin after removing from the solution, } \\
\text { but details of the time of observations } \\
\text { in the succeeding experiment prove that } \\
\text { the minimum possible is not less than } \\
\text { I53 for the rate of ascent of the eosin } \\
\text { per hour. }\end{array}$ & $\begin{array}{l}\text { The } \\
\text { shoots } \\
\text { were } \\
\text { exposed } \\
\text { to direct } \\
\text { sunlight } \\
\text { on a warm } \\
\text { breezy } \\
\text { July day } \\
\text { in the } \\
\text { morning. }\end{array}$ \\
\hline IO & 75 & $6 \cdot 5+I$ & $3^{\circ}$ & 240 & $\begin{array}{l}\text { This shoot was branched and ended } \\
\text { in a dead part of the main stem: the } \\
\text { measurement concerns the ascent up } \\
\text { the main stem and highest foliaged } \\
\text { branch. The time of the next observa- } \\
\text { tion absolutely proves that in this case } \\
\text { the lowest possible minimum rate of } \\
\text { ascent was I } 38 \mathrm{~cm} \text {. per hour. }\end{array}$ & \\
\hline
\end{tabular}


LARCH (continued).

\begin{tabular}{|c|c|c|c|c|c|c|}
\hline 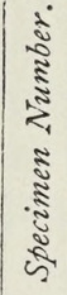 & 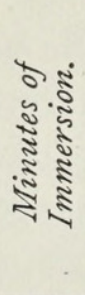 & 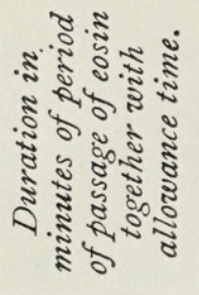 & 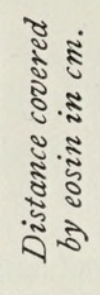 & 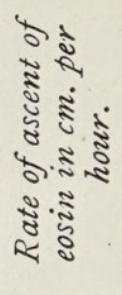 & & \\
\hline II & 80 & $3+I \cdot 5$ & $17 \cdot 5$ & 233 & $\begin{array}{l}\text { This shoot was unbranched, with the } \\
\text { foliage confined to the more terminal } \\
\text { parts; the dye had entered the foliaged } \\
\text { part. The time when the next observa- } \\
\text { tion was made proves that the lowest } \\
\text { possible minimum rate of ascent was } \\
\text { I } 3 \mathrm{Im} \text {. per hour. }\end{array}$ & \multirow{5}{*}{$\begin{array}{l}\text { The } \\
\text { shoots } \\
\text { were } \\
\text { exposed } \\
\text { to direct } \\
\text { sunlight } \\
\text { on a warm } \\
\text { breezy } \\
\text { July day } \\
\text { in the } \\
\text { morning. }\end{array}$} \\
\hline 12 & $\mathrm{I}_{4} \mathrm{O}$ & $5 \cdot 5+I$ & 3.5 & $3^{2}$ & & \\
\hline I 3 & I 45 & $6+I$ & $5 \cdot 5$ & 47 & & \\
\hline I 4 & I 55 & $4+2$ & $17 \cdot 5$ & I 75 & $\begin{array}{l}\text { This measurement records the rate of } \\
\text { movement up the leafless part of the } \\
\text { main stem and of the lowest long } \\
\text { branch among whose foliage the eosin } \\
\text { entered. The time of the next observa- } \\
\text { tion proves that the lowest possible } \\
\text { minimum rate of ascent was } 126 \mathrm{~cm} \text {. } \\
\text { per hour. }\end{array}$ & \\
\hline I 5 & 160 & $6 \cdot 5+I$ & $3-$ & $24-$ & $\begin{array}{l}\text { The eosin had ascended less than } \\
3 \mathrm{~cm} \text {, solely up the leafless basal part } \\
\text { of this branched shoot. }\end{array}$ & \\
\hline I 6 & IIO & $5+I$ & 13.5 & 135 & \multirow{3}{*}{\multicolumn{2}{|c|}{$\begin{array}{l}\quad \text { Set IV } \\
\text { Plants } \\
\text { exposed } \\
\text { to the } \\
\text { sun in an } \\
\text { afternoon } \\
\text { that was } \\
\text { moderately } \\
\text { bright, } \\
\text { and with a } \\
\text { consider- } \\
\text { able breeze } \\
\text { blowing. }\end{array}$}} \\
\hline 17 & 120 & $\mathrm{II} \cdot 5+\mathrm{I} \cdot 5$ & $17 \cdot 5$ & $8 \mathbf{I}$ & & \\
\hline I 8 & I 55 & 6 (or 7) & $7 \cdot 5$ & $\begin{array}{c}75 \text { (or } \\
64)\end{array}$ & & \\
\hline
\end{tabular}

SILVER FIR.

\begin{tabular}{|c|c|c|c|c|c|}
\hline I & I 70 & $16 \cdot 25+2$ & 18.25 & 60 & $\left.\begin{array}{l}\text { A branched well foliaged } \\
\text { shoot. The eosin had ascended } \\
\text { the main leafless stem past } \\
\text { one foliaged branch. }\end{array}\right\} \begin{array}{l}\text { Exposed to full } \\
\text { sunlight on warm, } \\
\text { sunny, breezy, } \\
\text { July midday. }\end{array}$ \\
\hline 2 & 125 & $11+1$ & $7 \cdot 5$ & $37 \cdot 5$ & Shoot about $45 \mathrm{~cm}$. long. \\
\hline 3 & ${ }^{1} 54$ & I 2 (or II) & $6 \cdot 5$ & $\begin{array}{c}32 \cdot 5 \text { (or } \\
35)\end{array}$ & $\begin{array}{l}\text { Shoot well foliaged, } 50 \mathrm{~cm} \text {. long. } \\
\text { But the apparatus was blown over in } \\
\text { the course of the experiment, so that } \\
\text { the shoot was not dipping in the eosin } \\
\text { throughout the whole time. }\end{array}$ \\
\hline
\end{tabular}


SCOTS PINE.

\begin{tabular}{|c|c|c|c|c|c|c|}
\hline 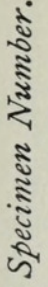 & 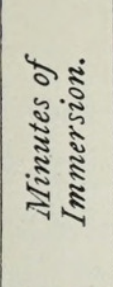 & 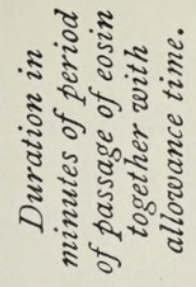 & 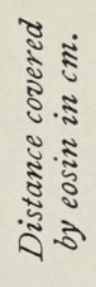 & 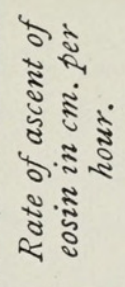 & - & \\
\hline 2 & $\begin{array}{l}\text { A } \\
\text { whole } \\
\text { day }\end{array}$ & $16 \cdot 5+3 \cdot 5$ & $3^{6+}$ & $108+$ & $\begin{array}{l}\text { The dye had reached the terminal } \\
\text { bud, so that the distance recorded is } \\
\text { probably not the full one that might } \\
\text { have been attained, hence the rate of } \\
\text { passage exceeds Io } 8 \mathrm{~cm} \text {. per hour. } \\
\text { The time of the next observation con- } \\
\text { clusively proves that the minimum } \\
\text { rate could not have been less than } \\
93 \mathrm{~cm} \text {. per minute. }\end{array}$ & $\begin{array}{l}\text { Shoots } \\
\text { exposed } \\
\text { to full } \\
\text { sunlight }\end{array}$ \\
\hline 3 & $\begin{array}{l}\text { A } \\
\text { whole } \\
\text { day }\end{array}$ & $10+I$ & 10 & $54 \cdot 5$ & $\begin{array}{l}\text { The dye had gone solely up the basal } \\
\text { leafless part of the shoot, which was } \\
30 \mathrm{~cm} \text {. long. }\end{array}$ & $\begin{array}{l}\text { on a bright } \\
\text { breezy } \\
\text { morning }\end{array}$ \\
\hline 4 & $\begin{array}{c}\text { A } \\
\text { whole } \\
\text { day }\end{array}$ & $\begin{array}{l}12 \cdot 5+2 \cdot 5 \\
12 \cdot 5+3 \cdot 5\end{array}$ & $\begin{array}{l}30+ \\
32\end{array}$ & $\begin{array}{l}\text { I } 20+ \\
\text { I } 20\end{array}$ & $\begin{array}{l}\text { The dye had gone up to the terminal } \\
\text { bud, hence the full possible distance is } \\
\text { not recorded, and hence the rate of } \\
\text { ascent may have exceeded I } 20 \text {. The } \\
\text { dye also went up a branch, as denoted } \\
\text { in the second statistics. }\end{array}$ & \\
\hline I & II 5 & $10+2$ & 6 & 30 & $\begin{array}{l}\text { The second measurements deal with } \\
\text { the journey of the eosin up the main } \\
\text { stem and a branch; while the first con- } \\
\text { cern the journey of the eosin up the } \\
\text { main stem only. }\end{array}$ & $\begin{array}{l}\text { Set IV } \\
\text { Afternoon: } \\
\text { breezy, } \\
\text { clear, and } \\
\text { warm. }\end{array}$ \\
\hline
\end{tabular}

PSEUDOLARIX.

\begin{tabular}{|r|c|c|c|c|c|}
\hline $\mathrm{I}$ & $\mathrm{I} 00$ & $5+\mathrm{I} \cdot 5$ & $3 \cdot \mathrm{I}$ & $28 \cdot 5$ & \\
2 & $\mathrm{I} 20$ & $6+\mathrm{I} \cdot 5$ & $6 \cdot 5$ & $52 \cdot 5$ & \\
3 & $\mathrm{I} 75$ & $9+\mathrm{I}$ & $\mathrm{I} 3$ & 78 & \\
\hline
\end{tabular}

BEECH.

\begin{tabular}{|c|c|c|c|c|c|c|}
\hline I & 35 & $23+I$ & $17+$ & $4^{2} \cdot 5+$ & $\begin{array}{l}\text { The dye had reached the terminal } \\
\text { bud, hence the distance and rate of } \\
\text { travelling of the eosin are not up to the } \\
\text { full possible. }\end{array}$ & $\begin{array}{l}\text { Set I } \\
\text { Warm, }\end{array}$ \\
\hline 2 & 70 & $6+I$ & $26+$ & $223+$ & $\begin{array}{l}\text { The eosin had reached the terminal } \\
\text { bud, hence the distance and rate of } \\
\text { travelling of the eosin are not up to } \\
\text { the possible full. }\end{array}$ & $\begin{array}{l}\text { breezy } \\
\text { morning. }\end{array}$ \\
\hline 3 & 90 & $7 \cdot 5+I$ & I9 & I 34 & & \\
\hline 4 & I 60 & $I_{5} 5+\mathrm{I}$ & 44.5 & 162 & $\begin{array}{l}\text { The eosin had ascended among the } \\
\text { foliaged branches of this branched } \\
\text { shoot. }\end{array}$ & $\begin{array}{l}\text { Cooler, } \\
\text { though } \\
\text { warm, less } \\
\text { breezy, } \\
\text { not sunny. }\end{array}$ \\
\hline
\end{tabular}


BEECH (continued).

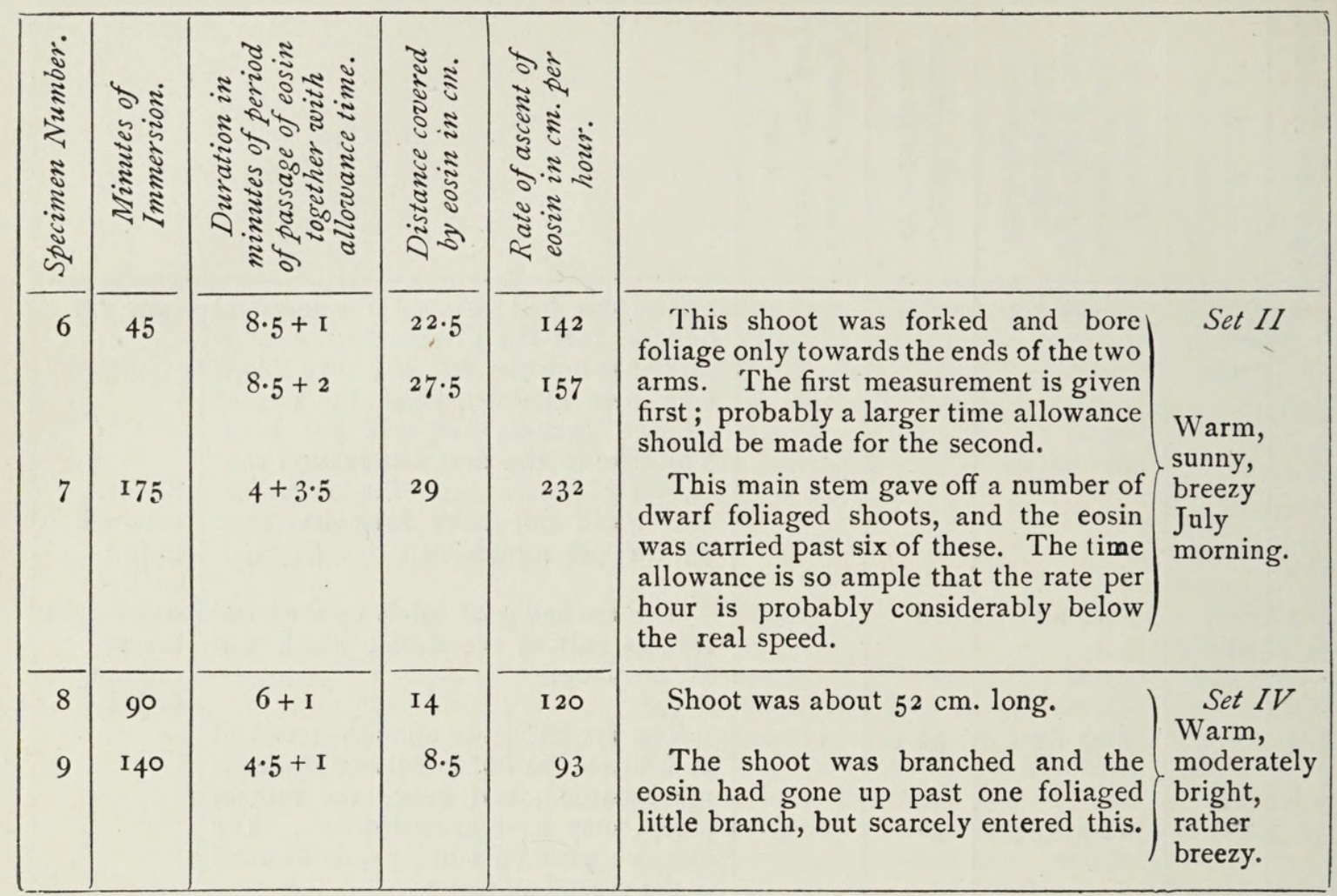

RATE OF ASCENT OF EOSIN IN CENTIMETRES PER HOUR.

(On same horizontal line the experiments synchronize in time to within fifteen minutes.)

\begin{tabular}{|c|c|c|c|c|}
\hline $\begin{array}{l}\text { Silver } \\
\text { Fir. }\end{array}$ & $\begin{array}{l}\text { Scots } \\
\text { Pine. }\end{array}$ & Larch. & Beech. & \\
\hline & & $\begin{array}{c}72 \cdot 5 \\
65 \\
177 \\
(110+) \\
38 \cdot 5 \\
75 \\
77\end{array}$ & $\begin{array}{l}(42.5+) \\
223+ \\
134 \\
162 \\
\\
\text { I10 }\end{array}$ & $\begin{array}{l}\text { Set I (July). } \\
\text { Morning: hot, sunny; fresh breeze } \\
\text { blowing : shoots exposed in the open } \\
\text { to direct sunlight. } \\
\left\{\begin{array}{l}\text { Afternoon : cooler (though warm), } \\
\text { a gentle breeze blowing, not so sunny: } \\
\text { plants exposed to full light. }\end{array}\right.\end{array}$ \\
\hline 60 & & $\begin{array}{r}142 \\
204 \\
240 \\
240 \\
32 \\
47 \\
175 \\
(24-)\end{array}$ & I $42($ I 57$)$ & $\begin{array}{l}\text { Set II (July). } \\
\text { Warm sunny morning with a breeze } \\
\text { Shoots exposed to direct sunlight. }\end{array}$ \\
\hline $\begin{array}{c}37.5 \\
32 \cdot 5 \text { or } 35\end{array}$ & 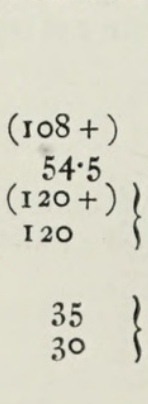 & 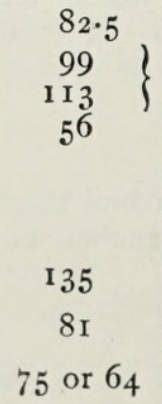 & $\begin{array}{r}\mathbf{1} 20 \\
93\end{array}$ & $\begin{array}{l}\text { Afternoon: not so sunny as in the } \\
\text { morning, yet warm: stronger breeze } \\
\text { than in the morning. }\end{array}$ \\
\hline
\end{tabular}


But apart from the positive results demonstrating the rapid rate of the transpiration current in the larch, we are not justified in the assumption that there is a universal and direct proportion between the habitual or maximum rate of transpiration of leaves and the calibre of vessels or tracheides. And it may be remarked here that Ewart's experiments, so far as they register rates of flow under the influence of transpiration, merely record the rate at which the eosin ascended, and the approximate rate at which the water ascended, under the conditions of transpiration then prevailing; but they do not record the rate at which water could easily ascend under a higher rate of transpiration, nor do they demonstrate that there is any universal rule that the calibre of the wood vessels is directly proportional to the rapidity of the transpiration current of a tree. It is true that in climbing plants where the transpiration current is known to be very rapid, the tracheae are notoriously wide. Ambronn and Westermaier explain this as an expression of the principle that the resistance to the travelling of water up tubes decreases with increase of diameter of these. Decrease or increase in diameter of the conducting tubes is only one of several possible arrangements to decrease or increase the transpiration current.

Von Höhnel's prolonged experiments supply us with statistics for comparing the rate of transpiration and the width of the vessels.

In the subjoined table the first column gives the name of the tree. The second and third represent the number of grammes of water transpired in 1878 (June to November) and in 1879 (April to November) per gramme dry weight of leaf. The fourth and fifth columns record my calculations of the rate of transpiration per square centimetre during the same periods. The sixth and seventh columns record the maximum rates of transpiration (in the months of June, July, or August, 1879) attained, reckoned respectively per gramme dry weight and per square centimetre of leafsurface. The eighth column gives the calibre attained by the wood vessels.

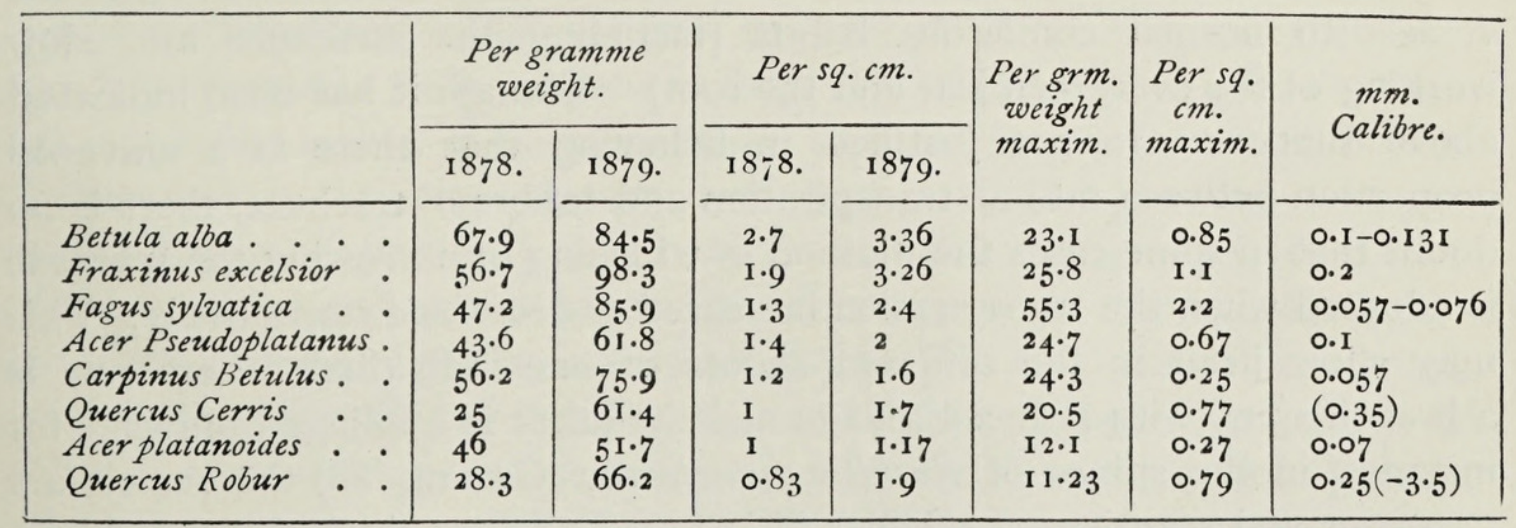

The figures giving the dimensions of the vessels are from Pedersen's pamphlet, except in the case of Quercus Cerris, which I measured. 
Ranging these statistics in order, by reckoning the largest as $\mathrm{I}$ and so forth to 8 , which is the smallest, the position taken by the respective trees as regards transpiration and calibre of vessels is as follows :-

\begin{tabular}{|c|c|c|c|c|c|c|c|}
\hline & \multicolumn{3}{|c|}{$\begin{array}{c}\text { Transpiration per grm. } \\
\text { dry weight. }\end{array}$} & \multicolumn{3}{|c|}{$\begin{array}{l}\text { Transpiration per square } \\
\text { centimetre. }\end{array}$} & \multirow{2}{*}{$\begin{array}{l}\text { Calibre } \\
\text { of vessel. }\end{array}$} \\
\hline & 1878. & 1879. & Maximum. & I 878. & 1879. & Maximum. & \\
\hline $\begin{array}{l}\text { 1. Betula alba } \\
\text { 2. Fraxinus excelsior. } \\
\text { 3. Fagus sylvatica. } \\
\text { 4. Acer Pseudoplatanus } \\
\text { 5. Carpinus Betulus. } \\
\text { 6. Quercus Cerris. . } \\
\text { 7. Acer platanoides. . } \\
\text { 8. Quercus Robur. . }\end{array}$ & $\begin{array}{l}\text { I } \\
2 \\
4 \\
6 \\
3 \\
8 \\
5 \\
7\end{array}$ & $\begin{array}{l}3 \\
1 \\
2 \\
6 \\
4 \\
7 \\
8 \\
5\end{array}$ & $\begin{array}{l}5 \\
2 \\
1 \\
3 \\
4 \\
6 \\
7 \\
8\end{array}$ & 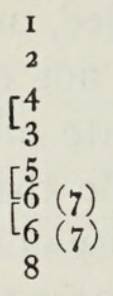 & $\begin{array}{l}\text { I } \\
2 \\
3 \\
4 \\
7 \\
6 \\
8 \\
5\end{array}$ & $\begin{array}{l}2 \\
3 \\
1 \\
4 \\
6 \\
5 \\
7 \\
8\end{array}$ & $\begin{array}{l}4 \\
3 \\
7 \\
5 \\
8 \\
1 \\
6 \\
2\end{array}$ \\
\hline
\end{tabular}

Where square brackets point to pairs of numbers these approach equality. According to calculations both by surface and by weight the three trees transpiring most rapidly are Betula, Fraximus, and Fagus. Of these, only one, Fraxinus, has vessels which come within the first three for size. While the lowest four as regards transpiration include Quercus Cerris and $Q$. Robur, which have the largest wood vessels. When the larch is included in the series, the lack of proportion between diameter of the conducting tubes and rate of transpiration becomes still more obvious.

\section{(c) Why have the Coniferae preserved the Tracheidal STRUCTURE OF THEIR WOOD?}

As tracheae ${ }^{1}$ have been evolved among Pteridophyta and occur in gymnospermous forms, we are not justified in assuming that the primitive Coniferae found it impossible to give rise to tracheae. The mechanism is such that it suffices not only for slowly transpiring leaves of evergreen conifers, but also for the rapidly transpiring ones of the larch.

There are, in fact, some reasons for believing that the tracheidal mechanism is better suited than would be a tracheal mechanism with wide vessels to normal coniferous habits (including the structure and slow working of the evergreen leaf and the root). Though it has been indicated above that we are not justified in believing that there is a universal proportion between rate of transpiration and calibre of tracheae, there is no doubt that in some cases the method of widening or narrowing the tracheae is adopted when the transpiration increased or decreased respectively. This may show itself in the different shoots of one individual, where one is a branch-spine with reduced foliage and the other is a foliaged branch; for instance, in the spines of Randia dumetorum (Groom, '92) the vessels are narrower and scantier. Lothélier ('93) found the vessels and parenchyma less developed in spines than in foliaged branches.

\footnotetext{
1 In this paper the terms 'trachea' and 'tracheal' solely refer to wood vessels.
} 
In different species of one genus at least some desert types show a decrease in the calibre of the tracheae when compared with mesophytic species. For instance, Volkens ('86) thus describes the wood of the small shrub Convolvulus lanatus: 'The wood-cylinder consists almost entirely of thick-walled libriform [fibres] and uniseriate medullary rays; and only after more close examination does one discover the few and narrow vessels.' Apparently, in a number of other desert species, the limitation of the waterconducting channel is accomplished rather by a diminution in the number of the vessels; for Volkens, describing the structure of the long, slender, poorly foliaged branches of Cocculus Leaeba, states that the 'waterconducting system consists mostly of tracheides with bordered pits', and scattered at intervals among these are 'tracheae of unusual width'. It is evident that the tracheae in desert plants are not always very small, for Volkens describes those of Zizyphus Spina Christi, which has small caducous leaves, as being 'unusually wide'. But the descriptions of the wood of desert plants are generally too vague as regards number and size of vessels; moreover, comparisons in these respects with more mesophytic species are required.

Yet it is clear that, in many cases, in xerophytic desert types there is a tendency towards reduction in size or number of tracheae. But this conclusion, drawn from plants growing in the Egypto-Arabian deserts, seems to be at variance with results obtained by Cannon.

Cannon ('05) has given an account of the comparative abundance and size of the tracheae in irrigated and non-irrigated specimens of identical species growing in the desert near Tucson (North America). His surprising results, which are illustrated by micro-photographs, must be regarded as absolutely reliable as regards facts. He found that on equal measured areas of the cross section the non-irrigated plants had more numerous and often wider tracheae. But in interpreting these results care must be taken, as Cannon used for observation stems of approximately equal thickness. But the irrigated stems thickened more rapidly than the non-irrigated. Hence the relatively smaller number of tracheae in the irrigated specimens may have been due to an increase in the width of the zone of growth, which was not balanced by a corresponding increase in the number of wide tracheae. For instance, a specimen of Quercus Robur growing in a poor situation (say on dry soil), when compared with one growing in a good situation, shows a larger number of wide tracheae in any measured area, because its annual rings are narrow and yet have a very heavy percentage or approximately the full number of wide tracheae. Again, as regards the width of the tracheae, comparison was made by Cannon between younger irrigated and older non-irrigated plants ; but we know that often at least, if not always, the width of the corresponding tracheae increases gradually outwards up to a certain limit in the successive annual rings. Hence the 
younger age of the irrigated specimens might be responsible for the smaller calibre of the vessels.

It is thus possible that the absolute number of vessels in any corresponding zone of growth in thickness (in an annual ring, if present) is greater in the case of the irrigated plants, and that even the width of the large tracheae is greater.

But another consideration arises in connexion with Cannon's results, namely, that since comparison was made between stems of equal thickness but unequal age, we do not know which stem bore a larger leaf-surface, nor which shoot had a larger transpiration.

It will be interesting if more critical comparison of the two kinds of individuals does show what Cannon's results at present apparently suggest, namely, that when these xerophytic individuals modify their foliage in a mesophytic direction, there is a tendency for a reduction in the number and calibre of the tracheae.

Even then, however, we should not be justified in concluding that the change of structure in the individual under changed circumstances marks out the line of evolution of the species under like prolonged changes of environment.

Thus the consideration of desert plants so far gives us no safe guide as to the structure of wood in relation to xerophytic foliage. And the question now arises as to whether there is any relation between the structure of the wood of a temperate species and the evergreen habit.

Examining the three tall British woody evergreen species-box, holly, and ivy-which seem to be oecologically allied to evergreen northtemperate conifers, we find that two of the three are characterized by the small calibre of their tracheae.

Buxus sempervirens has tracheae that are no greater in calibre than are the spring-tracheides of the Scots pine. Ilex Aquifolium has vessels that are scarcely wider. In Hedera Helix, the tracheae are neither scanty nor minute; though they are narrower than those of Bryonia and Clematis they are broader than those of Lonicera Periclymenum. Eliminating the climbing plant, the two others, like a number of cold-temperate Coniferae, thrive best in damp situations, and show the nearest possible tracheal approach to the tracheidal wood of Coniferae. In fact, all the evergreen trees of coldtemperate Europe, whether coniferous or dicotylous, have approximately the same xylem mechanism in their older stems. As the smallness of the number of these dicotylous trees prevents us from drawing the conclusion that the evergreen habit is linked with the narrowness of the tracheae, it seemed possible that an examination of one genus with deciduous and evergreen species might throw light on the question.

Accordingly, I measured the maximum size of the vessels in American deciduous and evergreen species of Quercus. The specimens used were 
from Hough's collection. To ensure uniformity of magnification, the vessels were drawn (with a camera lucida), and with the microscope immovably fixed at a focus giving a magnification of twenty diameters. In order to ensure impartial observation the actual drawings were made by Miss Beatrice Rhodes. For the measurements I am responsible. The resultant figures as to the actual diameter of the vessels were obtained by calculating the mean of the two diameters of two tracheae of each species.

In the subjoined tabular statement the statistics of the deciduous and evergreen species are given in parallel columns, viz. in the order of decreasing diameter of the tracheae.

\begin{tabular}{|c|c|c|c|c|c|c|}
\hline \multicolumn{3}{|c|}{ Deciduous Species. } & \multicolumn{4}{|c|}{ Evergreen Species. } \\
\hline & $\begin{array}{c}\text { Diameters of } \\
\text { two tracheae } \\
\text { magnified } \\
20 / 1 \text { in } \mathrm{mm} \text {. }\end{array}$ & \begin{tabular}{|c|} 
Mean \\
dia- \\
meter \\
in $m m$.
\end{tabular} & & $\begin{array}{c}\text { Diameters of } \\
\text { two tracheae } \\
\text { magnified } \\
20 / 1 \text { in } \mathrm{mm} .\end{array}$ & \begin{tabular}{|} 
Mean \\
dia- \\
meter \\
in $m m$.
\end{tabular} & \\
\hline 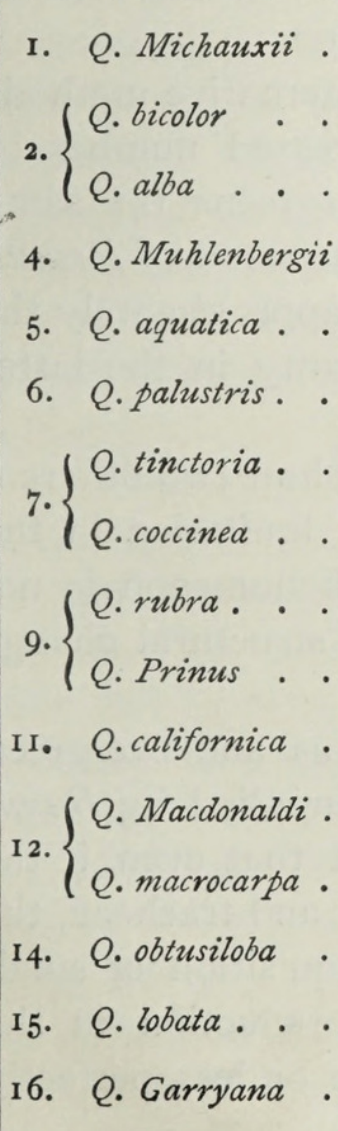 & 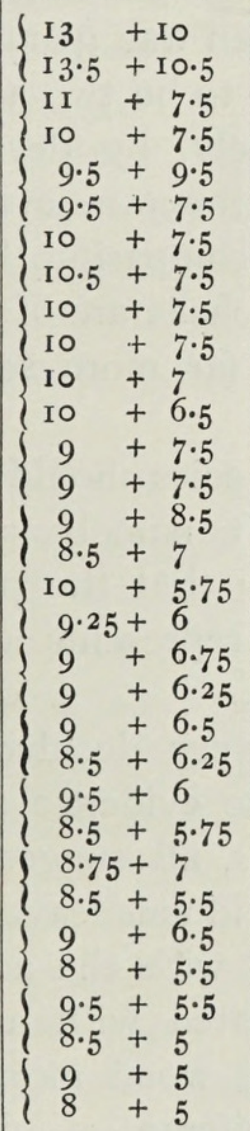 & $\begin{array}{l}0.5^{87} \\
0.45 \\
0.45 \\
0.444 \\
0.43^{8} \\
0.4^{19} \\
0.4^{12} \\
0.4^{12} \\
0.387 \\
0.387\end{array}$ & $\begin{array}{l}\text { Q. Emoryi. . } \\
\text { Q. chrysolepis. }\end{array}$ & $\begin{array}{l} \begin{cases}6 \cdot 5 & +4 \cdot 25 \\
6 & +4\end{cases} \\
\begin{cases}5 \cdot 5 & +3 \cdot 75 \\
5 & +5\end{cases} \end{array}$ & $\begin{array}{l}0.29 I \\
0.284\end{array}$ & $\begin{array}{l}\text { Sub- } \\
\text { ever- } \\
\text { green } \\
\text { or } \\
\text { sub- } \\
\text { deci- } \\
\text { duous. }\end{array}$ \\
\hline
\end{tabular}

There are several points worthy of notice in connexion with these results :-

I. The sixteen species with the widest tracheae are deciduous. And the leading six of these include the only four species that habitually grow in swampy places. The last of the series, Q. Garryana, is described by 
Sargent ('05) as growing on dry gravelly slopes and as having leaves 'thick and firm or subcoriaceous'.

2. The nine species with the narrowest tracheae are all evergreen. But of these, the five with the widest tracheae are what I may term 'subevergreen ' or 'sub-deciduous', as all their old leaves are cast off at the same time, or very shortly after, the new ones unfold in spring, while the four species having the narrowest tracheae are the only four that are typical evergreen.

Miss Beatrice Rhodes also measured the mean comparative diameters of the largest vessels 'of two to four-year-old twigs of three species of Fagus. They are less in the two evergreen South American species, Fagus Cunninghami $(0.0155 \mathrm{~mm}$.) and $F$. betuloides $(0.0225)$, than in the deciduous F. sylvatica $(0.03)$ and $F$. obliqua $(0.043)$, the latter of which is also South American. But the wood of an older piece of $F$. Cunninghami from Nördlinger's series gave a diameter of 0.057 , and that of an older stem of $F$. sylvatica a diameter of 0.052 . Undoubtedly the twig of $F$. Cunninghami was correctly named, as it came from a plant growing at Kew: there is no equal guarantee that Nördlinger's specimen was genuine.

But just as in desert types there seem to be two alternative methods of reducing the conducting channels, namely, by decreased number or decreased calibre of the tracheae, so in temperate evergreens the same appears to be the case. For I find that in comparing the wood of Prunus domestica with that of $P$. lusitanica the tracheae are of approximately the same size in the two species, but they are far more scanty in the latter species.

That desert types and these evergreen species should show two different methods of bringing about the same result, namely, a limitation in the number of wide tracheae, suggests strongly that the phenomenon is not merely a case of inevitable correlation, but represents a structural change directly beneficial to the species.

The remarkably exact agreement between deciduous and evergreen habit and width of tracheae in Quercus, the evidence supplied by Buxus and Ilex, and the divergent case of Prumus, all suggest that even if the ancestors of the Coniferae had possessed deciduous leaves and tracheae, the assumption of the evergreen habit, coupled with the acquisition of small xerophytic leaves, would have been associated with a reduction in the number or calibre of the tracheae, until the wood more or less perfectly agreed in structure with that of existing Coniferae.

Thus the question arises : Is there any evidence of evergreen dicotylous woody plants having undergone such a process of reduction in their wood? The Magnoliaceae and Trochodendraceae supply examples whose true interpretation may perhaps be the one suggested. Drimys, the magnoliaceous genus characterized by having its water-conducting tubes consisting of tracheides only, is evergreen and in austral regions marks the limit of its 
family as regards high latitude: it would be interesting to know if farther north the altitudinal limit is higher than that of other Magnoliaceae. The magnoliaceous Zygogynum also has wood of the same type, according to Van Tieghem ('00), but particulars concerning the exact habitat and evergreen or deciduous nature of the species seem to be lacking. The Trochodendraceae are composed of five genera. Of these Trochodendron and Tetracentron possess wood that is devoid of tracheae; while Cercidiphyllum, Euptelea, and Eucommia have true tracheae. Accordingly, we find that Trochodendron is evergreen: whereas Cercidiphyllum, Euptelea, and Eucommia are deciduous. Again, the evergreen Trochodendron with its tracheidal wood marks an extreme of distribution in the family as it occurs in the alpine region of Japan. Tetracentron sinensis is, however, deciduous, with leaves of hygrophytic structure. Yet its tracheides are much wider than those of Trochodendron, and at their dovetailing ends have very numerous pits with pit-membranes so extremely thin that the arrangement is the nearest approach to vessels with lattice-work perforations. It is interesting to note that the Trochodendraceae have their centre of preservation in China and Japan, where so many evergreen Conifers have been preserved: while Drimys Winteri, an extreme southern form, grows side by side with evergreen species of Fagus, austral Conifers, Myrtaceae, and Proteaceae, also species of Berberis and Ilex.

Degeneration of tracheal xylem to tracheidal xylem has certainly taken place in certain xerophytic species of Tillandsia (T. usneoides and others).

That this tracheidal structure of the evergreen north-temperate Coniferae is not a mere inevitable correlation phenomenon, but constitutes a mechanism that is best fitted to the evergreen Coniferae, is suggested also by the wide distribution and the survival of the Coniferae: and this question will be discussed later in the paper. Here I may merely indicate some possible advantages reaped by such temperate evergreen species through this tracheidal structure of the wood. It is easy to conceive that the acquisition of wider vessels would be a source of danger by facilitating a flow of water to the buds at times when available water was plentiful, and thus inciting the plant to produce a larger surface of foliage, and that of a less xerophytic type; such a change would bring with it the risk of injury or death from desiccation during either the physiologically dry or wet season. Again, we know that the rate of transpiration of a plant is greatly increased by increase in the rate of absorption and consequently of supply of water; it may therefore be that the narrowness of the tracheides (or tracheae) is itself a device for opposing resistance to the ascent of water, and for thus depressing transpiration. Strasburger ('91) demonstrated that more pressure is required to force water longitudinally through coniferous wood than through dicotylous wood possessing fair-sized vessels. 
Finally, the narrowing of the tracheae involves a relative increase in the strength of the wood, and a consequent opportunity for economy of material.

\section{(d) Rationale of the Xerophytism of the Coniferae.}

As already indicated, Schimper's theory, so far as water supply and water expenditure are concerned, explains the survival in north-temperate regions of the Coniferae which live in places where there is a physiologically dry season.

But, in seeking for a full explanation of the evolution and survival of Coniferae, it appears to me that one fundamental factor in their architecture has been overlooked, namely, the aggregate leaf-surface.

The amount of water emitted by a plant varies directly with the aggregate leaf-surface and the histological structure of the individual leaf. Now, if we imagine two plants, living within identical surroundings, to have equal powers of absorbing water, but one to have twice the leaf-surface of the other, then, if the one having the smaller leaf-surface just manages to retain sufficient water for its existence, it is obvious that the other will require more marked xerophytic structure in its foliage. Similarly, if there be two plants of equal leaf-surface, but unequal powers of absorbing water, and the one with the larger power of absorbing water contrives just to obtain and retain sufficient water, then the other will again have need of a more xerophytic type of leaf-structure. Such a type of xerophytism as is not evoked by edaphic or climatic agencies, but is dependent upon the organization of the plant itself, may be termed architectural xerophytism. And in any terrestrial community of plants, whether it be in an English meadow or a sub-tropical desert, one is apt to find a mixture of plants showing various grades of architectural xerophytism, mesophytism, and tropophytism; for instance, in a desert one can find growing side by side a deep-rooted plant with mesophytic foliage (e. g. the colocynth), a succulent tropophytic plant with delicate foliage (e. g. species of Senecio), and numerous typical xerophytes.

That the xerophytism of Coniferae is partly architectural in nature is demonstrated by several facts :-

I. Though the individual leaf is small the aggregate leaf-surface of the conifer often greatly exceeds that of the dicotylous tree.

In Table I, column 2, it will be seen that with specimens of equal age or size, the trees showing the largest aggregate leaf-surface are the Coniferae. (All the trees used by Von Höhnel in 1878 are described by him as being five to six years old and about 70 centimetres high.) The trees with the largest leaf-surface were Picea excelsa (I4,250 sq. cm.), Abies pectinata $(\mathrm{I} 2,400)$, Pinus sylvestris $(5,300)$; and the dicotylous trees most nearly approaching these were Acer platanoides $(4,500)$ and Alnus campestris 
$(4,000)$, while the other dicotylous specimens had considerably smaller aggregate leaf-surfaces.

2. Despite the low rate of transpiration of the single leaf or of a unit of its surface, at least some north-temperate Coniferae expend and need as much water as do ordinary dicotylous trees.

This is evidenced by Von Höhnel's results obtained in 1878 , as these represent the nearest approach to a minimum (see Table I, columns 4 and 5).

3. The need for a certain amount of water on the part of certain Conifers (spruce, silver firs, and some pines, \&c.) is demonstrated by the natural distribution of these trees, the experience of foresters, and by the failure to grow in Continental Europe certain Conifers that thrive when introduced to the more humid climate of the British Isles.

The conclusion to be drawn from these facts is that such is the aggregate leaf-surfaie of cold-temperate Conifers that even with their xeromorphic and xerophytic leaves numbers of species succumb from desiccation or grow feebly in places where ordinary dicotylous forest trees can thrive. It is therefore evident that were their foliage less xeromorphic or xerophytic, the result would be fatal unless the assimilating surface were reduced greatly. Such a reduction of the transpiring surface would involve a serious reduction in the assimilating organs and in the capacity of the tree to maintain itself as such.

As we have no comparative statistics in regard to the relative amount of assimilation and transpiration in different types of leaves within different surroundings, it is impossible to explain why the Conifer should have adopted the device of having a large aggregate surface with a greater degree of xerophytism. Yet a comparison with the oligotrophic smallleaved evergreen Ericaceae, the fact of the occurrence of various Coniferae on soils so poor that these species must be oligotrophic, and, finally, the existence of epiphytes with large leaves and xerophytic structure, cause one to hazard the guess that concurrent increases in the assimilatory surface and in the xerophytic devices generally increase assimilation in relation to transpiration.

\section{(e) The Efficiency of the Mechanism and the Survival of Coniferae.}

The statistics that I have given in regard to the width of the tracheae of the various species of Quercus might bear an interpretation different from the one stated above. It might be suggested that the evergreen species were the primitive ones, and that the evolution of the deciduous species was facilitated by the power of adding to the width of the tracheae. For, although the deciduous larch arose without any corresponding change in the water-conducting constituents, it is probable that increased width of the tracheae in more rapidly transpiring deciduous dicotylous trees is of use 
either in decreasing the resistance to flow or in providing wider reservoirs that more readily part with the contained water.

Hence, it remains to inquire if the evergreen habit associated with narrow water-conducting tubes provides an efficient and successful mechanism.

In the genus Quercus the evergreen species show a wide range of habitat and general distribution. Evergreen oaks occur in dry habitats (Mediterranean and North America), ascend to II,000 feet in the Himalayas, descend to the humid forests on the lower slopes of the Himalayas, and occupy truly tropical situations in the forests of IndoMalaya. They therefore show a wide range of habitat and general distribution.

Evergreen northern Coniferae, which have more reduced individual leaves, vie with or even surpass dicotylous trees in range of habitat and distribution. It is well known to foresters that sundry Conifers, including the Scots pine, can thrive on soils too poor for the successful cultivation of dicotylous forest trees. In the Northern Hemisphere, not only in temperate but in tropical regions, they take possession of less favoured sites on mountains and hills. But on more favourable situations on mountains in Europe, North America, and Asia they can give rise to forests and defeat dicotyledons. In some instances at least, the Conifer defeats the dicotyledon in favourable sites; thus in the battle between two shade-enduring species, Abies pectinata and the beech, the former is sometimes the victor and drives its foe before it (for instance, in the Schwarzwald in Würtemberg). R. Gradmann ('00) has given an interesting analysis of the struggle between Picea excelsa and Fagus sylvatica in southern Germany. $\mathrm{He}$ shows that the victor below 400 metres is the beech, but above I, 000 metres the spruce; while the belt between 400 and I,000 metres altitude is the region of a ceaseless struggle in which soil often decides the result, as the spruce is usually victorious on sandy soil and the beech on calcareous soil, but even on the latter soil heavy battalions of spruce may drive the beech on to the driest sites. Other examples of the defeat of dicotyledons (oak for instance) by spruce might be given. In India, Pinus longifolia, $P$. Khasya, and P. Merkusii form forests at altitudes at which tropical vegetation is wont to prevail.

Again, judged by range of the single species, the coniferous mechanism shows its efficiency. Funiperus communis in its ordinary form extends from arctic regions and alpine altitudes in the cold-temperate region down to the Mediterranean shores, where it reaches sea-level. As an oligotrophic plant it grows on sunny rocks, the driest dune-sands, dry heaths, and soaking sphagnum bogs; yet it can thrive on good soil and in less lighted places, and grow as underwood even in shady forests of silver firs and beech in northern Europe, or in moist misty country in southern Europe. 
Funiperus recurva, occurring at an altitude of 16,000 feet on the Himalayas, yet thrives in Calcutta Botanic Gardens (but without flowering in the latter place, as Colonel Prain informs me). The Scots pine occurs in extremely varied habitats, as is notorious.

The genus Pinus shows a climatic range of distribution that I believe to be unequalled by any dicotylous arboreous genus. Occurring in arctic regions (at $70^{\circ} \mathrm{N}$.), it extends southwards to the Equator (in Sumatra); and in southern Burma has one species, P. Merkusii, occupying a truly tropical position at only 500 feet above sea-level. Pinus includes species growing beyond the altitudinal and latitudinal limit of forest. Some species live in good soils in company with dicotylous trees and demand moist air; others occur in Mediterranean and Californian regions among sclerophyllous vegetation, often on particularly dry sites ; still others grow in dry sterile sands or in swamps of various types (peat-bogs, wet sand, muddy swamp).

The mechanism that permits of such range of single species or genera must be an efficient one under very diverse circumstances, and must afford ample explanation of the survival of modern Coniferae. Certainly the plasticity of the coniferous evergreen foliage of one species is usually underestimated, first because its most obvious feature concerns differences in the length of the needles (which differences may exceed I,000 per cent.), but the needles also show change of thickness and surface, and above all they exhibit great differences as regards longevity, so that the Scots pine, for instance, may prolong the life of some of its needles from the average 2-3 years to 8-9 years. The general impression that the evergreen northtemperate Conifer as a working machine is inferior to that of the deciduous dicotylous tree in the same region is, perhaps, a mistaken one. The two types of trees may represent rather two alternative mechanisms of approximately even efficiency when in normal action ; and the low-tension coniferous machine in places outworks its high-tension tropophytic rival.

\section{$(f)$ The Vulnerability and Suppression of Coniferae.}

If then the coniferous mechanism in normal working really be as efficient as the dicotylous mechanism, it would seem possible that the defeat of the Coniferae by dicotylous trees and the suppression of many forms are due to the coniferous machine being more easily put out of order or being more exposed to injury.

In connexion with the second alternative, there is no doubt that the tree preserving its xerophytic leaves during the physiologically dry season, or in extremest conditions, is exposed to greater danger of desiccation than is a tree that is devoid of foliage during the same season. Though, as Von Höhnel points out, we cannot rely upon his results as regards the amount of water given off by trees during winter (as the trees were kept under shelter in a room), the results sufficiently indicate the greater loss of water 
by Conifers during that season. Yet despite of this, evergreen Coniferae advance into the extremest positions in the cold-temperate region. Although Larix sibirica reaches $72^{\circ} 30^{\prime} \mathrm{N}$. as a prostrate shrub, Pinus sylvestris and Funiperus communis reach $70^{\circ} \mathrm{N}$., and $\mathcal{F}$.communis var. nana goes at least as far north as $7 \mathrm{I}^{\circ} \mathrm{N}$. Again, while Larix decidua ascends to an altitude of 2,400 metres in Switzerland, this limit is equalled in the same country by Pinus montana and surpassed by Funiperus communis var. nana. Yet it is possible that in its tree-form Larix is better capable than any other conifer of enduring extreme cold, and we know that Taxodium distichum advances into an extreme habitat of another kind, namely swamp. Moss ('07) gives statistics suggesting that in north-temperate types certain deciduous species attain higher latitudes and altitudes than do allied evergreen species. In this connexion it may be pointed out that in the tall evergreen humid forests of Burma and the Malabar Province, the majority of the tallest trees are deciduous, and tower above the lofty trees which produce the main roof of the high forest : again, some of the few giant trees that are evergreen are only sub-evergreen, as they cast off the old leaves with the appearance of the new foliage. Yet in these forests, too, some of the tallest trees are evergreen, so that we cannot absolutely say that those exposed to the extremest condition are deciduous, though the tendency is in this direction.

There is one clear distinction between coniferous and dicotylous trees, namely, in their power of withstanding equal injurious influences that suddenly damage the tree. Coniferae succumb more readily, whether the injuries be wrought by chemical or cultural agencies, or by animals or plants.

Despite of the wide range of distribution of such species as Funiperus communis, Mayr arrives at the conclusion that Conifers are less capable than are dicotyledons of acclimatizing themselves. Mayr's view is probably correct, when we limit its scope to the relatively short periods during which attempts at acclimatization have been made and to the attempts made where the climate is continental.

In regard to chemical injuries, it is well known that Conifers, less sensitive than certain deciduous dicotylous trees to the action of sulphur dioxide, are, nevertheless, more easily killed by smoke. The cause here is triple. First, the leaves are exposed to the influence of smoke for a longer time; secondly, the aggregate leaf-surface is often larger than in the case of dicotyledons; thirdly, the sulphur dioxide of smoke kills leaves that required several years for their production.

In connexion with the last cause, it may be noted that complete defoliation, especially if repeated once or twice, of an evergreen conifer by insects, fungi, or other agencies, leads to the death or at least serious weakening of the tree; whereas a deciduous dicotylous tree may suffer defoliation 
regularly each year (as in the case of the oak attacked by the leaf-roller moth) and continue to exist. The larch, being deciduous, rather resembles the deciduous dicotyledon in this respect, for repeated partial defoliation by the caterpillars of the little moth Coleophora laricella does not cause its death.

Bark-beetles easily cause the death of Conifers if the attack be severe or sustained; whereas birches, ash-trees, and elms can endure for many years severe attacks from the familiar species of bark-beetles that infest them. In this respect the larch seems rather allied to the evergreen conifers. Cortical injury to the larch by the canker-fungus, Dasyscypha calycina, varies in its result, but in numbers of cases the tree can resist this fungus for more than sixty years.

Even larvae tunnelling in the wood kill evergreen Conifers more readily than they do dicotylous trees.

Finally, Colonel Prain informs me that in Calcutta Botanic Garden coniferous trees thoroughly shaken by the wind, though not uprooted, seem to die more readily than dicotylous tress. To what extent this is due to the evergreen character in a climatically deciduous region or to tardy replacement of the injured roots it is impossible to say.

The causes of the greater vulnerability of the conifer are varied and perhaps partially obscure. When all the leaves of the tree are destroyed the evergreen Conifer loses what required years to produce and will require years to replace, and at the same time the tree is partially deprived of the assimilating organs required to manufacture the material for replacing the missing members. In addition, the coniferous plant is endowed with less power of replacing the missing leaves, as it has neither the wealth of dormant buds nor the power of emitting adventitious shoots possessed by a dicotylous deciduous tree. An exception to this rule prevails in the yew, which can withstand severe clipping, though this is fatal to most Conifers.

It is worthy to note that evergreen Coniferae have a larger number of serious fungal and insect foes than have dicotylous trees in north-temperate regions. This may be wholly, or only partially, another method of stating the proposition that the Conifers are more readily killed or injured.

To prove the statement I have drawn up lists of tree-attacking Fungi and insects from the recognized textbooks on the diseases of trees by Hartig, Von Tubeuf, and Judeich and Nitsche.

I give below a table showing the number of Fungi attacking forest trees, first as given in Hartig's 'Diseases of Trees', and thus as enumerating the ones that were so obviously important as to be investigated first, and secondly, as given in Von Tubeuf's 'Diseases of Plants'. In my lists I originally grouped fungal diseases into four classes :-

I. Those fatal to the tree.

2. Those severe, and causing much injury to the living tree. 
3. Those that are less severe, and may be merely leaf-diseases from which the tree usually or always recovers.

4. Others, concerning whose precise significance we are not fully informed, but which are probably largely not of first-class importance.

In the table below, the first two classes are grouped together as severe and the last two as slight; the estimates of the severity or lenience of the diseases are my own.

The dicotylous trees are infected by I $_{5}$ severe fungal diseases, of which II are limited to them, while the Coniferae are attacked by 25 severe fungal diseases, of which $2 \mathrm{I}$ are restricted to them: the remaining 4 affect dicotyledons and Conifers. Of the I5 attacking dicotyledons, 8 are wood-destroying Fungi that do not infect coniferous wood; while of the 25 serious fungal foes of Coniferae only 6 are limited to wood (there are others attacking both wood and cortex). As the Fungi attacking heartwood can hardly be regarded as of first-class severity, if they were excluded from the lists the disparity between dicotyledons and Conifers would be further increased.

\begin{tabular}{|c|c|c|c|c|c|c|}
\hline \multirow{2}{*}{ Species. } & \multicolumn{6}{|c|}{ Number of parasitic fungal diseases. } \\
\hline & \multicolumn{3}{|c|}{ Enumerated by Hartig. } & \multicolumn{3}{|c|}{ Enumerated by Von Tubeuf. } \\
\hline & Severe. & Slight. & Total. & Severe. & Slight. & Total. \\
\hline Abies pectinata & I 2 & 2 & I4 & $14-15$ & $3^{-2}$ & I7 \\
\hline Picea excelsa. & I $7-18$ & $4-3$ & $2 \mathrm{I}$ & I9 & 3 & 22 \\
\hline Pinus sylvestris & IO-II & $4-3$ & 14 & I $8-20$ & $6-4$ & 24 \\
\hline Larix decidua. & $8-9$ & $2-I$ & I0 & $9-10$ & $2-I$ & II \\
\hline Quercus Robur & IO-II & $3-2$ & I3 & IO & I 4 & 24 \\
\hline Fagus sylvatica & $4-5$ & $3-2$ & 7 & 6 & 9 & I 5 \\
\hline Betula alba. . . & 2 & 4 & 6 & 3 & 14 & I 7 \\
\hline Carpinus Betulus & I & 2 & 3 & $2-3$ & $7-6$ & 9 \\
\hline Alnus glutinosa. & $2-3$ & $4-3$ & 6 & $I-3$ & I $2-10$ & I3 \\
\hline Fraxinus excelsior & I & 0 & I & $I-3$ & $6-4$ & 7 \\
\hline
\end{tabular}

Similarly, in regard to insect foes, I have drawn up lists of the various insects attacking forest trees in Europe, using as the source of information 'Lehrbuch der Forstinsektenkunde', by Judeich and Nitsche: the results are given in the columns $2-7$ of the succeeding table. These diseases I have ranged into several classes: $(a)$ severe, and attacking young plants (seed-beds and nurseries, \&c.); (b) slight, and attacking young plants; (c) severe, and attacking older trees; $(d)$ slight, and attacking older trees. There is a certain vagueness in the classification because I have had to use my judgement, first, as to whether the disease is severe when it does attack the tree, and secondly, as to whether it is sufficiently common on the tree to be reckoned as a menace; but diseases caused by insects that rarely attack the species I have reckoned as 'slight'. In order to check my estimate I have drawn up the list of insect foes that attack the same species of forest trees 
and are admittedly of such importance as to be included in the small work on 'Forest Protection' by Fürst; the results are given in column 8 of the same table. The results of both methods of estimating agree in showing the larger number of insects menacing the existence of coniferous species.

NUMBER OF SPECIES OF INSECTS ATTACKING.

\begin{tabular}{|c|c|c|c|c|c|c|c|c|}
\hline \multicolumn{2}{|l|}{ Species. } & \multicolumn{2}{|c|}{ Young trees. } & \multicolumn{2}{|c|}{ Old trees. } & \multicolumn{2}{|c|}{$\begin{array}{l}\text { Grand Total } \\
\text { (young and } \\
\text { old }) .\end{array}$} & \multirow[t]{2}{*}{$\begin{array}{l}\text { No. of species } \\
\text { of prime } \\
\text { importance } \\
\text { attacking. }\end{array}$} \\
\hline & & Severe. & Total. & Severe. & Total. & Severe. & Total. & \\
\hline Abies pectinata & . & 3 & 20 & 6 & 27 & 9 & 47 & 16 \\
\hline Picea excelsa & . & $2 \mathrm{I}$ & 64 & 10 & 57 & $3 \mathrm{I}$ & I2I & 30 \\
\hline Pinus sylvestris & . & 33 & 67 & 20 & 67 & 53 & I 34 & $3^{2}$ \\
\hline Larix decidua & - & 8 & I4 & 7 & 37 & I 5 & $5^{\mathrm{I}}$ & 20 \\
\hline Fraxinus excelsior & . & 2 & 2 & o & I 8 & 2 & 20 & 6 \\
\hline Fagus sylvatica . & . & $I_{4}$ & $\mathrm{I} 7$ & 8 & $4^{6}$ & 22 & 63 & I9 \\
\hline Betula alba. - & . & 5 & I3 & I & 50 & 6 & 63 & 13 \\
\hline Carpinus Betulus & - & $\circ$ & 3 & 0 & I6 & 0 & I9 & 6 \\
\hline Alnus glutinosa. & $\therefore \quad$. & 5 & 6 & 4 & 42 & 9 & 48 & 5 \\
\hline Ulmus campestris and & U. montana & 0 & $\circ$ & 2 & 37 & 2 & 37 & 9 \\
\hline
\end{tabular}

(The number of slight diseases is obtainable by subtracting the 'severe' from the 'total' in the respective cases. The total number of insects listed was 385 .)

Columns 6 and 8 are worthy of special comparison.

Of the insects mentioned here as attacking young trees, 102 species attack the Conifers only, I 8 attack the Conifers and dicotyledons, and I5 species attack the dicotyledons only. Thus, on the average, each Conifer has 25.5 exclusive foes or 30 inclusive foes, while each dicotyledon has 2.5 exclusive foes or 5.5 inclusive foes. Similarly, attacking old trees, I 2 I are confined to the Conifers, 8 damage the Conifers and dicotyledons, while $\mathrm{I}_{3} \mathrm{I}$ are confined to the dicotyledons. On the average each conifer is attacked by 30.25 exclusive foes or 32.25 inclusive foes, and each dicotyledon by $2 \mathrm{r} \cdot 8$ exclusive or $23 \cdot \mathrm{I}$ inclusive foes.

Thus dicotylous trees (at least in north-temperate climes) may owe their victory over Coniferae in the majority of favourable sites largely to their power of resisting or repairing injury caused by sudden hostile influences, including animal and fungal foes. It is possible, too, that in secular changes of climate Coniferae suffered more than dicotyledons, though certain coniferous genera, such as Pinus, betray no signs of inability to secular acclimatization. So far as the chief forest trees are concerned, insect-pollination appears to have played but a small part in aiding the north-temperate dicotyledons. 


\section{SUMMARY.}

I. The northern evergreen Coniferae are architectural xerophytes in which the extensive surface exposed by the evergreen leaves as a whole renders it necessary for the individual leaves to be xeromorphic in form and xerophytic in structure. This type of structure enables these Coniferae to live in regions where there is a season of physiological drought, in situations varying from dry dunes to moist forests, and from arctic and alpine situations to tropical sites.

2. The tracheidal structure of the wood of these conifers is well suited to their xerophytic evergreen leaves; and a similar type of wood is apt to occur in north-temperate and austral-temperate dicotyledons that have evergreen xerophytic leaves, as is shown by American species of Quercus, Trochodendron, and Drimys. The tracheidal structure of the wood is not a bar to progress and to the adoption of the deciduous habit, for in the larch a rapid transpiration current flows through it and the leaves transpire rapidly. The tracheidal structure of the wood more probably provides the conifer with a safety mechanism that is a defence against extinction.

3. Conifers are more easily deranged and killed by sudden injuriẹs, and are attacked by a larger number of serious fungal and insect foes, than are dicotylous trees. To their greater vulnerability and smaller powers of repairing injuries we may at least partially attribute the defeat and extinction of many Conifers in past ages.

In conclusion I beg to express my thanks, first to Lt.-Col. Prain, F.R.S., Director of the Royal Botanic Gardens, Kew, for permitting me to perform the physiological experiments at the Jodrell Laboratory, and for some of the material used in this investigation; and secondly, to Messrs. James Veitch \& Sons for twigs of Tetracentron.

\section{LITERATURE.}

\footnotetext{
Cannon ('05): On the Water-conducting system of some Desert Plants. Botanical Gazette, xxxix, pp. 397-408.

Ewart ('05): The Ascent of Water in Trees. Phil. Trans. Royal Soc. B., p. 52.

Gradmann, R. ('00): Das Pflanzenleben der Schwäbischen Alb. Tübingen, 2. Aufl., Theil i, p. 327. Groom, Percy ('92): On the Thorns of Randia dumetorum. Annals of Botany, vi, p. 375 .

HöHnEL, F. von ('79) : Ueber die Transpirationsgrössen der forstlichen Holzgewächse. Mittheil. aus dem forstl. Versuchswesen Oesterreichs, Bd. ii, Heft i, p. 47.

('80): Weitere Untersuchungen iiber die Transpirationsgrössen der forstlichen Holzgewächse. Jbid., Bd. ii, Heft iii.
} 


\section{Groom.-Remarks on the Occology of Coniferae.}

LothÉLIER ('93): Recherches sur les plantes à piquants. Revue générale de botanique, v. MAYR: Quoted in Schimper's Plant Geography.

Moss, C. E. ('07) : Xerophily and the Deciduous Habit. New Phytologist, vi, p. 183.

Pederssen, O. G. ('01): Diagnostik Vedanatomi .... Copenhagen.

Sargent, C. S. ('05): Manual of the Trees of North America. London and New York.

Schimper, A. F. W. ('90): Ueber Schutzmittel des Laubs gegen Transpiration, ... Monatsber. der Berliner Akademie d. Wissenschaften, vii.

('98): Plant Geography. English Version (1903), pp. 564-5, Oxford.

$\rightarrow$ Stopes, M. C. ('07): The 'Xerophytic' Character of Gymnosperms. New Phytologist, vi, p. 46.

Strasburger, E. ('91): Ueber den Bau und die Verrichtungen der Leitungsbahnen in den Pflanzen. Jena.

Van Tieghem ('00): Sur les Dicotylédones du Groupe des Homoxylées. Journal de Botanique, xiv, p. $34^{\circ}$.

Volkens ('86): Die Flora der ägyptisch-arabischen Wïste. Berlin. 


\section{$2 \mathrm{BHL}$ Biodiversity Heritage Library}

Groom, Percy. 1910. "Remarks on the oecology of Coniferae." Annals of botany 24, 241-269. https://doi.org/10.1093/oxfordjournals.aob.a089266.

View This Item Online: https://www.biodiversitylibrary.org/item/262605

DOI: https://doi.org/10.1093/oxfordjournals.aob.a089266

Permalink: https://www.biodiversitylibrary.org/partpdf/319774

\section{Holding Institution}

New York Botanical Garden, LuEsther T. Mertz Library

\section{Sponsored by}

BHL-SIL-FEDLINK

\section{Copyright \& Reuse}

Copyright Status: Public domain. The BHL considers that this work is no longer under copyright protection.

This document was created from content at the Biodiversity Heritage Library, the world's largest open access digital library for biodiversity literature and archives. Visit BHL at https://www.biodiversitylibrary.org. 